\title{
Efetividade E Tutela Jurisdicional
}

\section{Carlos Alberto Alvaro de Oliveira*}

\author{
"Il ne fautjamais awoirpeurd' aller troploin, carla zéritéestau-delá". \\ Marcel Proust (Correspondance générale, IV)
}

1. O problema fundamental da filosofia é o existir na condição humana, vale dizer, com a consciência da próptia finitude. Para o direito, o "to be or not to be" é a questão da sua própria realização. Mesmo que não se concorde com a Zweckjurisprudenz de R. Jhering, não se pode deixar de atribuir plena razão ao jurista alemão quando proclamava que "O direito existe para se realizar. A realização do direito é a vida e a verdade do direito; ela éo próprio direito. $O$ que não passa à realidade, o que não existe senão nas leis e sobre o papel, não é mais do que um fantasma de direiro, não são senão palavras. Ao contrário, o que se realiza como direito é o direito..." razão essencial para que as coisas se compreendam assim. É que também no direito - e sobretudo no direito como entidade prática - a determinação da "essência" não comprova a "existência": o direito não é (não é direito) sem se manifestar na prática e como prática. Não temos direito só porque pensamos a essência jurídica ou a juridicidade, ou porque construímos um sistema de normatividade jurídica - teremos quando muito a possibilidade (ideal) do jurídico e nada mais. Só o cumprimento histórico-concreto, naquele modo de ser que é a vigência e que the permite afirmar-se como efectiva dimensão da prática humanosocial, transforma a juridicidade em direito"'.

* Professor Titular de Direito Processual Civil da Faculdade de Direito da Universidade Federal do Rio Grande do Sul (Ensaio destinado a livro en homenagem a Egaz. Dirceu Moniz de Aragão)

1 R. Jhering, L'Esprit du droit romain, MI, p. 16, apud Castanheira Neves, Metodologia Juridica - Problemas Fundamentais, Coimbra, Coimbra Editora, 1993, p. 25.

${ }^{2}$ Castanheira Neves, Metodologia, cit., p. 25. 
No plano do direito processual, a questão tem tudo a ver com a eferividade do instrumento processual, tanto em termos de tempo quanto de conteúdo dos pronunciamentos judiciais, com vistas à justiça do caso concreto, e observancia das garantias do devido processo legal.

Todavia, se quisermos pensar o direito processual na perspectiva de um novo paradigma de real efetividade, é preciso romper de ver com concepções privatústicas e atrasadas, que não mais correspondem às exigências atuais e que deixaram de ser adequadas às elaboraçōes doutrinárias e aos imperativos constitucionais que se foram desenvolvendo ao longo do século XX. Nesse panorama, um dado importante é o declínio do normativismo legalista, assumido pelo positivismo jurídico, e a posição predominante, na aplicação do direito, dos princípios, conceitos jurídicos indeterminados e juízos de equidade, com toda sua incerteza, porque correspondem a uma tomada de decisão não mais baseada em um prius anterior ao processo, mas dependente dos próprios elementos que nele serão colhidos.

Consideradas essas premissas, mostra-se inadequado continuar a pensar as relações entre o direito material e o processo em termos de ação de direito material, conceito que só tinha razão quando ainda não estava suficientemente maduro o arcabouço dos diteitos fundamentais e a constitucionalização que se seguiu. Mais ainda: impõe-se prestar atenção à idéia de tutela jurisdicional, mais consentânea com os valores imperantes em nossa época, especialmente aqueles consagrados no plano constitucional ${ }^{3}$. Trata-se, em suma, de atentar devidamente à noção autônoma e de carárer público da ordem processual, decorrente da necessánia monopolização da distribuição da Justiça pelo Poder estatal.

Indispensável, outrossim, desligar-se de concepções unilaterais, que só cnxergam a norma ou o fato, sem incluir o valor, como requer uma visão necessariamente totalizante do fenômeno jurídico. A esse respeito, tenho ressaltado que o plano dos fatos trabalha com efeitos físicos, próprios do mundo natural, como acontece com a evaporação da água, efeito de seu aquecimento a $100^{\circ} \mathrm{C}$. Já o mundo jurídico lida com valores, e o efeito (jurídico) da norma não é nem o simples valor nem o simples fato, mas o valor atribuído ao fato, conforme o enquadramento realizado pela norma. Nisso reside o specificum do fenômeno juridico, constituído sempre de fato valorado pela regra jurídica ${ }^{4}$. Sob esse ângulo visual, não

3 A tutela dos direitos, como se sabe, pode ser dispensada pela via jurisdicional ou näo jurisdicional (e.g., por meio da arbitragem). De outro lado, a jurisdiçäo pode não exibir a função de tutelar direitos, como na jurisdição penal ou na jurisdição que cuida dos interesses de modo semelhante à atividade desenvolvida pela administração pública, a chamada jurisdição voluntária (a respeito, Francesco P. Luiso, Diritto Processuale Civile, vol. I, Principi Generali, 3a. ed., Milano, Giuffre, 2000, p. 9). No presente ensaio, tratax-se-á exclusivamente da tutela jurisdicional de direitos.

4 Alvaro de Oliveira, Comentários ao Código de Processo Civil, vol. VIIt, t. II, $3^{2}$ ed, Rio de Janeiro, Forense, $1998, \mathrm{n}^{\circ} 5, \mathrm{p} .11, \mathrm{n}^{\circ}$ 9, p. 21, ibidem na $7^{3}$ ed, $2005, \mathrm{n}^{\circ} 5$, p. 12, $\mathrm{n}^{\circ}$ 9, p. 22. Com razão, pondera Torçuato Castro, Teoria da situação jurídica em direito privado nacional, São Paulo, Saraiva, 1985, p. 94-95, passim, que o direito năo é produto do espírito puro, nem dos fatos (visão idealista e positivista), sendo insuficiente só falar em fato, porque o fato pressupõe um valor para a causalidade juridica, atribuído pela norma. 
se pode deixar de teconhecer que os valores humanos não pertencem apenas ao mundo ideal, mas têm um fundamento real, que é uma realidade da experiência histórica e social, não uma realidade metafísica. Só assim será possível estudar a positividade do direito como realidade empírica dos valores de ação expressos pelas proposições normativas (realidade empírico-formal) e predispostas em função dos interesses eminentes da sociedade (realidade empírico-substancial) ${ }^{5}$.

Evidentemente, o problema da eferividade enseja diversos planos de abordagem. No presente ensaio, pretendo examinar a questão tão somente pela ótica conceitual, começando pelas relações entre o direito material e o processual, tema relativamente recente e que teima por desafiar uma solução satisfatória.

2. No periodo clássico do direito romano, o resultado do litígio dependia da actio concedida ao autor pelo Pretor, que foi adquirindo com o passar dos tempos também um significado material. O monismo - a existência de um só plano, que abrangia tanto o direito material quanto o processual - era evidente porque a actio caracterizava ao mesmo tempo "o direito privado que era prometido com a formula e o ordenamento que lhe estava subjacente, para exigir do demandado o seu cumprimento e, caso necessátio, promover sua realização mediante o processo c a execução" ". Na perspectiva do direito romano, a pretensão privada, para cuja realização a actio era outorgada, não aparecia como um direito subjetivo totalmente constituído. Via-se nela, pura e simplesmente, o reflexo da tutela juridica inaugurada com a admissibilidade da actio ${ }^{7}$. Realmente, por um longo período da evolução do sistema jurídico romano, a rutela jurídica dos interesses em grande parte não era constituída previamente por normas materiais, mas confiada ao processo, por meio de normas instrumentais. Exatamente com vistas a tal função, o processo estruturava-se em duas fases, ius e indicium. Por tal motivo, cm principio a actio não era um direito, mas o único direito concedido para a tutela dos interesses. Desse modo, o direito subjetivo processual não se mesclava com o direito subjetivo material, por ser o instrumento para a constituição deste, que antes do processo não existia. Semelhante circunstância histórica explica porque, mesmo depois da autonomia conquistada pela figura do direito subjetivo material, a ciência jurídica não estava pronta para esclarecer as relações que vieram a se estabelecer entre ele e a ação, de modo a tomar clara a distinção entre direito subjetivo material (de natureza privada) e direito subjetivo processual (de natureza pública) ${ }^{8}$. Talvez isso ajude a compreender a razão de ter

5 Assim, Angelo Falzea, Introduzione alle scienze giuridiche, parte prima (ll concetto del diritto), $5^{\mathrm{a}} \mathrm{cd}$. revista, Milano, Giuffrè, 1996, p. 260-272.

6 Max Kaser, Das römische Zivilprozessrecht, München, Beck, 1966, \$32, II, 2, p. 173.

? CF. Apostolos Georgiades, Die Anspruchskonkurrenz im Zivilrecht und Zivilprozessrecht, München, Beck, 1968 , p. 12, com remissão aos ensinamentos de Kaser e Jörs-Kunkel-Wenger.

\& Cf. as Lícidas observações de F. Carnelutti, Sistema di Diritto Processuale Civile, vol. I, Funzione $e$ composizione del processo, Padova, Cedam, 1936, $\mathrm{n}^{\circ} 356$, p. $889-890$. 
sido também monista a concepção elaborada pelo Direito das Pandectas, embora privilegiasse o plano do direito material.

Para Savigny, o direito de ação (Klagerecht) era considerado como uma forma especial assumida pelo direito material depois da lesão, uma espécie de metamorfose extensível a todo direito". Já na visão de Puchta, Arndts e outros, tratava-se de um acessório do direito material, uma "faculdade colada ao direito, a permitir o pedido de tutela jurisdicional se este fosse violado"10.

Como se vê, conquanto diferentes as visualizações, tanto no direito romano, quanto no direito comum, o direito processual e o direito material formavam uma unidade, o que embaçava distinção nítida entre os dois planos.

Apenas com a célebre polêmica entre Windscheid e Muther (1856-1857) começouse a colocar na ordem do dia a questão da separação entre o direito processual e o direito material, destruindo-se a unidade da actio (compreensiva do direito material e processual) ${ }^{11}$.

$\mathrm{Na}$ visão de Windscheid, a pretensão é o poder jurídico de exigit a prestação em juizo. Absorve-se, assim, o conteúdo substancial da actio no conceito de pretensão, circunstância que evidentemente veio a favorecer a concepção meramente processual ou publicística da ação' ${ }^{12}$. Nada obstante, Windscheid ainda não se desprega totalmente da concepção de Savigny. Continua a falar em ação de direito material e em lesão, embora doutrine que a única lesão a direito a ter como conseqüência a concessão imediata de tutela jurisdicional é a em que entram ao mesmo tempo em conflito a vontade do causador do dano e a vontade do titular do direito. Para ele, porém, nos direitos reais a lesão do direito de propriedade não cria um direito de acionar, mas apenas um direito creditório para que se sane a lesão. Negada a satisfação, esse direito de crédito se transformará em direito de acionar (Klagerecht). Assim, todos os direitos reais (direitos sobre coisas) adquirem, com a lesão, uma relação pessoal que até então não tinham, transformando-se em direitos creditórios, vale dizer, em pretensão (Anspruch) contra o causador do dano ${ }^{13}$.

9 Nessa perspectiva, como ressalta G. Pugliese, Polemica intorno all' "actio", Firenze, Sansoni, 1954, p. XIV, a actio (ou a ação de direito material) era um direito novo, surgido da lesão de outro direito.

${ }^{10}$ Savigny, System, V, $\$ \$ 204,205$, Puchta, Pandekten, $\$ 81$, Vorlesugen, 1 , p. 183 e ss., Arndts, Lebrbuch, $\$ 96$, apud 3. Binder, Prozess und Recht - Ein Beitrag zur Lehre vom Rechtsschutzanspruch, Neudruck der Ausgabe Leipzig 1927, Aalen, Scientia Verlag, 1969, p. 1.

"Andreas Kollmann, Begriffs- und Problemgeschichte des Verbältnisses von formellen und materiellem Recht, Berlin, Duncket \& Humblot, 1996, p. 576.

12 Pugliese, Polemica, cit., p. XXII. O mesno autor, ob. cit, p. XXXIV-XXXVI, adverte ainda que 0 conceito de pretensão adotado por Windscheid é ambiguo, pois tanto se refere ao poder de exigir en juizo o direito (iudicio persequendi) quanto ao propprio direito (quod sibi debeatur), conforme a conhecida máxima de Celso, definidora da actio: ius quod sibidebeaturiudicio persequendi. A isso se soma a própria ambigüidade da língua alemâ, em que Anspruch significa, polissêmicamente, não só "pretensão", "exigência", mas também "direito".

${ }^{13}$ Bernhard Windscheid, Die Actio des römischen Zivilrechts vom Standpunkte des beutigen Rechts, Düsseldorf, 1856, Neudruck, Aalen, Scientia Verlag, 1984, p. 222-223. 
Dentro desse contexto, foi principalmente a critica de Muther, depois incorporada por Windscheid, que propiciou a criação dos elementos necessários para uma nova concepção, na medida em que distingue claramente um direito à tutela do Estado, direito de agir, a que se atribui natureza pública, restando intocado o direito material apesar da lesão ${ }^{14}$. Dessa forma, Muther opõe-se ao conceito de "Metamorphose" defendido por Savigny, na medida em que nega a existência de um especial direito ou pretensão à ertadicação da lesão contra o causador da lesão ${ }^{15}$, reconhecendo apenas um direito de natureza pública do lesado contra o Estado, de outorga de tutela estatal (o direito de ação, Klagerecht), e o direito do Estado contra o causador do dano para a erradicação da lesão $0^{16}$.

A partir dessa idéia, Windscheid reconhece também a legitimidade de uim conceito de ação material junto com uma ação processual. Essa admissão constitui sem dúvida alguma o maior fruto da polêmica travada entre os dois juristas alemães. $O$ direito de ação no sentido material é a pretensão jurídica material, pela qual é dada com a ação a autorização de realizar - por meio da "contraposição da vontade do obrigado e da vontade do titular do direito "- aquilo que se reclama do adversário, o que dele se exige no sentido material". $\mathrm{O}$ direito de ação em sentido processual, em contrapartida, é o "direito à tutela do Estado" (Recht auf Hülfe des Staates), não integrando o direito material, mas o processual ${ }^{18}$.

Como se constata, Windscheid - principalmente em face das criticas de Muther, às quais veio a aderir - ulttapassa em larga medida a concepção dominante no seu tempo. Não apenas restou destruída a unidade até então existente entre o direito material e o direito de ação, mas também foi concedida substância própria à teoria processual no domínio da doutrina do direito de ação, substância que teoricamente até então esta não exibia, pois tudo era deixado aos cuidados do direito civil, cujos resultados eram geralmente apropriados pela ciência processual ${ }^{19}$.

"Muther, ob. cit, p. 43: "So haben wir zwei einander correspondirende Rechte, beide publicisticher Natur: Das Recht des Vefletzen gegen den Stat auf Gewährung der Staastshülfe (das Kagerecht) und das Recht des Staats gegen den Verletzer auf Aufhebung der Verletzung". Ver a respeito, Oliver Vossius, Zu den dogniengeschichtlichen Grundlagen der Rechsschutzlebre, IBbelsbach, Verlag Gremer, 1985, p. 163, nota 14.

"Windscheid, Die Actio des römischen Zivilrechts, cit., 1984, p. 44, 73, 76-77, 222; Abwebr gegen. Theodor Muther, Düsseldorf, 1857, Neudruck, Aalen, Sciendia Verlag, 1984, p. 29; Lehrbuch des Pandektenrechts, Bd. I, 4. Auflage, $1875, \$ 122$, nota 5 .

${ }^{13}$ Windscheid, Abwher, cit, p. 26 e 29.

${ }^{10}$ Cf, a observação de Wilhelm Simshäuser, Zur Entwicklung des Verbältnisses von materiellem Recht und Prozessrecht seit Savigny - Eine Untersuchung am Beispiel rechtsfremder Klagen, Bielefeld, Verlag Ernst und Werner Gieseking, 1965, p. 79. 
Um outro passo importante para a autonomia do direito processual foi dado por Wach, ao estabelecer um direito concreto de demandar, que se consubstancia na chamada pretensão à tutela jurídica, formada com elementos de direito material e processual, devendo a ambos unir. A pretensão à tutela jurídica é entendida como a pretensão de uma das partes em face do Estado a tutela jurídica favorável correspondente a uma situação jurídica, que pode ser pretensão a uma sentença condenatória, declaratória ou constitutiva, ou pretensão executiva para a realização de uma pretensão de direito material por via da execução forçada, ou pretensão à segurança para satisfação da pretensão mediante arresto ou medidas cautelares. A pretensão à tutela jurídica corresponde a uma das partes, já a pretensão à sentença, ao autor ou ao demandado. É exercida contra o Estado, como titular do Poder Judiciário, e contra o tribunal, como seu órgão, em face do adversário, para que este suporte o ato de tutela. Tratase, portanto, de uma pretensão de direito público, cujo conteúdo é a finalidade de obtenção de turela jurídica. No âmbito do processo de conhecimento, essa finalidade é alcançada com uma sentença definitiva favorável. Diferencia-se da pretensão de direito marerial e, particularmente, da pretensão de direito privado perseguida pelo autor com a demanda, pois esta se dirige contra o demandado, de quem é exigido o cumprimento da prestação devida, e aquela contra $o$ Estado, do qual se reclama a tutela jurídica. $O$ demandado pode satisfazer a pretensão de direito material, mas não a pretensão de tutela jurídica. Esta só é sátisfeita com um ato de tutela jurídica favorável e se extingue com isso. Por seu turno, a satisfação da pretensão de direiro material nada mais faz do que deixar sem objeto a pretensão de tutela jurídica ${ }^{20}$. Embora a ampla aceitação da teoria de Wach na Alemanha até o primeiro quartel do século passado ${ }^{21}$, formou-se lentamente um consenso que sua doutrina não corresponde à realidade das coisas.

Leo Rosenberg bem resume as críticas realizadas na Alemanha à teoria de Wach. Ambas as partes têm pretensão à outorga de justiça, não apenas uma delas, mas não a uma tutela jurídica favorável. $O$ órgão judicial deve resolver a controvérsia de acordo como o direito material, seja a favor do autor, seja a favor do demandado. O que existe é a pretensão de ambas as partes ao exame e resolução da demanda, de acordo com o sistema jurídico, seja material seja processual. Mesmo a pretensão à execução significa apenas o dever do órgão estatal de empregar as medidas estabelecidas pelo Estado para sua realização, e não que a execução redunde em tesultado favorável para o credor ${ }^{22}$.

20. A. Wach, Handbuch des Deutschen Civilprozessrecbts, tomo I, Leipzig, Duncker \& Humblot, 1885, p. 19-22, 116 119, passim, Der Feststellungsanspruch - Ein Beitrage zur Lehre vom Rechtsschutzanspruch (Sonderabdruck aus der Festgabe der Leipiziger Juristenfacultät für B. Windscheid zum 22.Dezember 1888), 1889, p. $14-15,18-23,27,31-33$, passim.

21 Para tanto, basta atentar no livro de Georg Schüler, Der Urteilanspruch - Ein Beitrag zur Rechtsschtuzlebre und zum materiellen Justizrecbt, Tübingen, I. C. Mohr (Paul Siebeck), 1921, em que são vigorosamente defendigas as idéias de Wach.

${ }^{22}$ Leo Rosenberg, Lebrbuch des Deutschen Zivilprozessrecht, 9. Auflage (úlitima publicada en vida do autor), München, Beck, 1961, \$90, p. 433-436. Outros aspectos críticos, ressaltad́os por Rosenberg, não são aqui reproduzidos por não dizerem respeito ao tema. 
As idéias de Wach ganham outra roupagem com a teoria do direito justicial (Justizrecht), desenvolvida por James Goldschmidt, também partidário da ação como diteito concreto.

No seu sentido juridico rigoroso, trata-se, para ele, de um domínio jurídico (ou de uma norma), que "tem como objeto uma relação jurídica entre a Justiça estatal e a pessoa individual" ${ }^{23}$. Tanto o direito processual civil quanto o direito processual penal pertencem ao direito justicial, na verdade ao direito justicial formal. Ambos "regulam o lado formal, ou de exercício, da relação jurídica entre o Estado e a pessoa individual"24.

Ao lado do direito justicial formal, elabota Goldschmidt o conceito de direito justicial material, que seria o direito privado material orientado contra o Estado. Argumenta que seo Código Civil prescreve regras de direito privado, também contém "uma imagem não-escrita", que se dirige ao Estado (à Justiça) e estabelece o conteúdo da sentença ${ }^{25}$. O direito justicial material constitui, portanto, uma função do direito privado (subjetivo) material, transformado pela orientação conrra o Estado. Para Goldschmidt, o fenômeno fundamental do direito justicial (civil) material centra-se no conceito de pretensão à rutela jurídica, "descoberto" por Wach, relacionando os elementos materiais, pré e extraprocessuais, ao direito privado material ${ }^{26}$. Nessa perspectiva, "só pode ser considerado direito justicial materjal o direito regulador, o lado material da relação justicial civil, construído, vale dizer, sob o ponto de vista da pretensão à tutela jurídica de Wach, do indivíduo contra o Estado"27.

O direito justicial material compreende a totalidade das normas relativas à pretensão de tutela dirigida contra o Estado. Além disso, determina o conteúdo da sentença, por meio de normas imperativas dirigidas ao juiz, revelando-se para a pretensão à tutela jurídica como "o direito subjetivo do direito justicial civil material"28. Assim, a pretensão à tutela juridica e o direito privado material, pensado em sua direção contra o Estado, pertencem ao mesmo campo e, sob esse ponto de vista, são quase idênticos. $O$ direito civil, em sua direção contra o Estado, determina o conteúdo da sentença, constituindo nessa função, junto à pretensão de tutela jurídica, direito justicial civil material ${ }^{20}$. Impõe-se ressaltar que, ao classificar a pretensão

${ }^{23} \mathrm{~J}$. Goldschmidt, Materielles Justizrech (Rechtschutzsanspruch und Strafrecht), Festgabe für Dr. Bernhard Hübler, Berlin, Verlag von Franz Vahlen, 1905, p. 86.

${ }^{24}$ Goldschmidt, Materielles Justizrecht, cit., p. 86 e ss., esp. p. 87.

${ }^{2.5}$ Goldschmid, Zwei Beitrăge zum materiellem, Über Begriff und Bedeutung des materiellem Ziviljustizrechts, Sonderabdruck aus der Festgabe für Bernhard Hübler, p. 119-120, Der Prozess als Rechtslage - Eine Kritik des prozessualen Denkens, 2. Neudruck der Ausgabe Berlin 1925, Aalen, Scientia Verlag, 1986, p. 240-241.

${ }^{26}$ Goldschmidt, Ziviljustirecht, cit.., p. 127-129, Zivilprozessrecht, Neudruck der 2. Auflage Berlin 1932, Aalen, Scientia Verlag, $1969, \$ 1$ ', p. 2.

${ }^{27}$ Goldschmidt, Materielles Justizrecht, cit., p. 87-89: "Vielmehr ist materielles Justizrech nur" das die materielle Seite des Ziviljustizverhälnisses als solche regelnde Recht, d. h. konstruiert unter dem Gesichtspunkt des Wach 'schen Rechtsanspruchs der Gliedperson gegenüber den Stat".

${ }^{28}$ Goldschmidt, Materielles Justizrecht, cit., p. 87-88, 99-10, Ziviljustizrecht, cit., p. 109 e 120.

${ }^{29}$ Goldschmidt, Zivilprozessrecht, cit., $\$ 12$, p. 52. 
à tutela jurídica como um fenômeno exclusivamente material, Goldschmidt afasta-se nesse aspecto flagrantemente de Wach.

Em consonância com essas idéias, Goldschmidt classifica como normas jurídicas materiais não apenas as que regulam a pretensão à tutela jurídica, mas também a acionabilidade do direito material. $O$ mesmo enquadramento é realizado em relação às regras sobre prova e sobre a coisa julgada material, já que elas influenciamo conteúdo da sentença e não apenas o procedimento.

Para Goldschmidt, a pretensão à tutela jurídica pertence ao direito material, embora apresente natureza processual, constituindo assim um direito justicial material ${ }^{30}$. Trata-se, portanto, de um ponto de vista diverso ao da actio clássica, pois esta conquanto constituísse expressão do direito material exibia natureza rigorosamente processual ${ }^{35}$. Por outro lado, a classificação de fenômenos processuais no direito material, por força da teoria da direito justicial material, assemelha-se fortemente ao conceito de actio de Savigny e do Direito das Pandectas.

Com base nessas premissas, Goldschmidt adota uma visão preferivelmente empirica do fenômeno processual, ${ }^{32}$ dirigida a uma determinação finalística do processo: a finalidade do processo seria "a produção da coisa julgada", a tutela do direito subjetivo privado constituiria, porém, finalidade do direito justicial materia ${ }^{33}$.

Finalmente, na visão de Goldschmidt, o direito de ação (Klagerecht), a que também denomina pretensão ì sentença (Urteilsanspruch), constitui um dirteito público subjetivo de tutela jurídica dirigido apenas contra o Estado, com vistas à obtenção de uma sentença favorável ${ }^{34}$. Classifica, por outro lado, o direito de ação, ençuanto objeto concreto do processo (o meritum causae), como direito justicial material e não processual ${ }^{35}$. Acentua, ainda, ser perfeitamente possivel separar hoje o direito de ação contra o Estado e a pretensão privada contra o obrigado, conquanto fossem indistintos os dois direitos no horizonte da actio romana ${ }^{36}$.

Importante ressaltar, outrossim, que mesmo em Plósz, fundador juntamente com Degenkolb da teoria da ação abstrata, ainda ressoam ecos do conceito de ação material.

${ }^{30}$ Goldschmidt, Materielles Justizrecht, cit, p. 98: "Assim, impóe-se forçosa e necessariamente ver na pretensão de tutela jurídica $\mathrm{um}$ direito material, sem divida de natureza processual, em uma palavra um direito justicial material". Adiante, ob. cit, p. 120 , reafirna que o direito justicial material é "o próprio direito civil, repensado como essência (ou a mais alta representação) das regras de relacionamento entre o individuo e os deveres de tutela jurídica do estado".

3 Andreas Kollmann, Problemgeschichte, cit., p. 598, chega mesmo a afrumar que se cuida de posição diametralmente oposta à da actio clássica, ponto de vista do qual discordo, porque não leva em conta o caráter bifronte do direito justicial material.

${ }^{32}$ Goldschmidt, Der Prozess als Rechtslage, cit., p. 146 e ss., 150.

${ }^{33}$ Goldschmidt, Zivilprozessrecht, cit., $\$ 1^{\circ}$, p. 1 e s.

${ }_{34}$ Goldschmidt, Zivilprozessrecht, cit., $\$ 12,1$ e 2, p. 52.

35 Goldschmict Zivilprozessrecht, cit., $\$ 12,3$, p. 52 .

3/ Goldschmid, Zivilprozessrecht, cit., $\ 12,1, \mathrm{p} .52$. 
Para este último, o direito de ação (Klagerecht) revela-se independente da existência do direito material. Necessário tão somente que o autor afirme um direito reconhecido e atenda a todas as suas exigências ou, na hipótese da ação declara tória, um interesse juridico, estando na convicção subjetiva de que o direito efetivamente exista. A expectativa do autor não diz respeito a uma sentença favorável, mas a uma sentença conforme a lei, nem constitui pressuposto da a ção a verdade do fato jurídico afirmado pelo autor como relevante, mas apenas a própria afirmação do fato jurídico ${ }^{37}$. Posto isso, Degenkolb distingue entre o direito de ação processual (Klagerecht) e a acionabilidade do dircito material (Klagbarkeit). Esta é colocada exclusivamente no plano do direito material, como uma qualidade anexa ao direito material, como fundamento para servir ou poder servir à ação ${ }^{38}$.

Já para Plósz, há dois direitos de ação, o direito de ação material (materielles Klagerecht), identificado com a pretensão material, e o direito de ação formal processual (formales prozessualisches Klagerecht), concebido como direito de estabelecimento do processo, de natureza pública, dirigido contra o tribunal e o demandado ${ }^{37}$. O direito de ação processual não ostenta como pressuposto a existência do direito subjetivo privado nem decorre da violação do direito, e tampouco se identifica com o direito privado violado ${ }^{40}$. O seu exercicio vinculase exclusivamente à introdução de certas afirmações "acionáveis", principalmente a afirmação da existência de um direito privado ${ }^{4 ?}$.

3. No ambiente cultural, ora esboçado de maneira sintética, a teoria de Pontes de Miranda sobre a ação ${ }^{42}$ constituiu, sem dúvida, um admirável tour de force para superar as polêmicas que então grassavam a respeito do tema, buscando encontrar uma explicação para as questões decorrentes das relações entre direito material e direiro processual.

${ }^{3}$ Heinzich Degenkolb, Einlassungszwang und Unteilsnorm - Beiträge zurmateriellen Theorie der Klagen insbesondere der Annerkennungsklagen, Neudruck der Ausgabe Leipzig 1877, Aalen, Sciencia Verlag, 1969, p. 32-33, 41. 42.

${ }^{34}$ Degenkolb, Einlassungszwang, cit., p. 55. Ėm obra posterior, Degenkolb, Beiträge zum Zivilprozess, 2. Neudruck der Ausgabe Leipzig 1905, Aalen, Scientia Verlag, 1987, p. 8, ressalta as seguintes diferenças entre a sua teoria e a de Plósz: a) Plósz estabelece dois direitos de ação: um processual, de caráter público, outro material, Je caráter privado, o que é rejeitado por cle, Degenkolb; b) Degenkolb restringe o direito público de ação à demanda aforada com boa-fé; Plósz rejeita essa limitação.

${ }^{39}$ Alexander Plósz, Beiträge zur Theorie des Klagerechts, Leipzig, Vetlag von Duncker \& Humblot, 1880, p. 5 e ss., 30 e ss. e 103 e ss. Conforme esclatece o próprio Plósz no prefácio da ediçào alemã, a primeira parte dos ensaios coligidos nesta obra, sobre o direito de ação, foi originariamente editada em húngaro en 1876, no fascículo de março e abxil da revista Magyar Igazságügy e também en separata. A mesma informação consta da obra de Degenkolb, Beiträge, cit., p. 8, nota 1.

${ }^{40}$ Plósz, Beiträge, cit., p. 13 e 14.

${ }^{41}$ Plósz, Beiträge, cir., p. 11,17, 40.

42 Pensada, vale ressaltar, nos anos 30 do século XX (data de 1934 a $1^{2}$. edição de $A$ Aç̧ão Rescisória contra as Sentenças), quando as idéiass de Wach ainda exerciam forte influência na Alemanha . 
Na sua primeira elaboração, proclamava Pontes de Miranda que "a ação supõe o direito objetivo que a dê e fato que constitua razão de seu exercício. Por isso mesmo não se identifica com o dever do sujeito passivo. Se o direito subjetivo tende à prestação, a ação, que supõe haver-se transgredido a norma, constituj outro plus e tende, não à prestação, mas a efeito jurídico específico" "43. Argumentava que os direitos subjetivos e as ações não se confundem ${ }^{44}$, exemplificando com direitos subjetivos sem ação, mas ao mesmo tempo afirmava que "a ação pertence ao corpo mesmo do direito material, é intrínseca ao dircito que a tem, e os que não a têm só não a têm porque cles mesmos foram nascidos sem ela ou a regra objetiva a fez precluir ou prescrever" ${ }^{45}$. Por isso concluía que "a ação é instituto do Direito material, e não do Direito formal ou processual" 46.

No plano do direito processual, não fala em ação, mas tão somente em remédio processual ${ }^{47}$. Este é conceituado como "meio instrumental, que o direito formal põe a serviço de pessoas que estejam em determinadas condições, para que, com o uso dele, possam suscitar a decisão, a prestação jurisdicional" "48 . O direito subjetivo e a ação preexistem ao exercício, ao uso, dos remédios processuais ${ }^{49}$. Mais adiante acentua: "O remédio processual é conferido a quem quer se ache nas condições de propô-lo, variando apenas os pressupostos de legitimação ativa e passiva. O que dele se utiliza pode ter ou não ter ação. A ação é direito a reclamar. Não é o direito subjetivo, que já definimos, nem o direito-meio que os Estados conferen com os remédios processuais. O direito de ação não é contra determinado Estado, o que dele faria direito público subjetivo; mas a admissão por parte do direito mesmo que cria a relação, a reclamar a un Estado, - o que estabelece o remédio, o Estado do foro (....) A ação é determinada, concreta, atribuída a alguém ou a certa categoria, e não indeterminada, abstrata, universal" 50. Universais, até certo ponto, indeterminados, abstratos, são os remédios processuais, para os quais, ainda assim, a lei determina pressupostos de legirimação ativa e passiva, que atenuem a possibilidade de serem usados por todos (universalidade), independentemente das ações que tenham (abstração) e do objeto (indeterminação) ${ }^{51}$. A ação é dirigida não contra o Estado, mas contra o legitimado passivo: a ação do marido para anular o casamento, por já estar deflorada a mulher, tem por titular o marido e por sujeito passivo a mulher ${ }^{52}$.

${ }^{43}$ Pontes de Miranda, $A$ Ação Rescisória contra as Sentenfas, Rio de Janeiro, Livraria Jacinto, 1934, $\ 3,1$, p. 14-15.

44 Pontes de Miranda, A Ação Rescisória contra as Sentenças, cit., \$3, 2, p. 15.

${ }_{5}$ Pontes de Miranda, $A$ Aç̧ão Rescisória contra as Sentenças, cit., $\$ 3,5$, p. 17.

4 Pontes de Miranda, $A$ Acção Rescisória contra as Sentenças, cit, $\$ 3,5, \mathrm{p} .17$.

${ }^{47}$ Pontes de Miranda, $A$ Ação Rescisória contra as Sentenças, cit., $\$ 3,7, p .19$.

4* Pontes de Miranda, A Ação Rescisória contra as Sentenças, cit., $\$ 4,4$, p. 24.

49 Pontes de Miranda, A Aç̧ão Rescisória contra as Sentenças, cit., $\$ 4,2$, p. 21 .

${ }^{50}$ Pontes de Miranda, $A$ Acção Rescisória contra as Sentenças, cit, $\$ 4,2$, p. $22-23$.

5Pontes de Miranda, A Aç̧ão Resciśória contra as Sentenças, cit., $\$ 4,2, \mathrm{p} .22-23$.

52 Pontes de Miranda, A Aç̧ão Rescisória contra as Sentenças, cit., $\$ 4,3$, p. 23. 
A última formulação data de $1970{ }^{53}$. Nesta o elemento um tanto ambíguo do remédio jurídico processual ${ }^{54}$ perde força, sem desaparecer totalmente, pela introdução de outro elemento, a ação processual ("ação"), à qual por vezes é equiparado. Surge também o conceito de pretensão à tutela jurídica, que nada obstante a denominação não se confunde com a pretensão à tutela jurídica de Wach ${ }^{55}$. Igualmente novo é o conceito de pretensão material, que para certos efeitos veio a substituir a ação de direito material.

A ação de direito material, a actio, "supõe, sem necessitar, o direito objetivo, que a dê, e fato, que constitua a razão de seu exercício. Por isso mesmo, não se identifíca com o dever do sujeito passivo. Se o direito subjetivo tende à prestação, surgem a pretensão e a ação. A ação, que supõe haver-se transgredido a norma, constitui outro plus e tende, não à prestação, mas a efeito jurídico específico" ${ }^{56}$. Em outra passagem, empregando ação sem aspas c, portanto, no sentido de ação de direito material, sustenta que "A ação é inflamação do direito ou da pretensão" 57 . A ação (de direito material) exerce-se principalmente por meio da "ação" (remédio jurídico processual), isto é, exercendo-se a pretensão à tutela jurídica que o Estado criou ${ }^{58}$.

Afirma serem inconfundíveis os direitos subjetivos, as pretensões e as ações, dando exemplos para demonstrar o asserto ${ }^{59}$.

Distingue: a) direito público subjetivo à justiça; b) pretensão à tutela jurídica; c) pretensão material, que se vai "invocar" em júzo (não exercer) e d) ação que se vai "mover"'. A respeito da pretensão à tutela jurídica, escreve Pontes de Miranda: "Quando se propõe uma ação, qualquer que seja, exerce-se a pretensão pré-processual, que é a pretensão à tutela jurídica, pois o Estado, desde que se estabeleceu o monopólio estatal da Justiça, a essa tutela

${ }^{53}$ Refiro-me ao Tratado das Açôes, tomo I, cujà 1 1ª edição data de 1970, São Paulo, Revista dos Tribunais, não levando em consideração os Comentários ao Código de Processo Civil, tomo I (1974), visto que os conceitos daquele são meramente reproduzidos neste.

54 Conforme F. H. Lawson, Remedies of English Law, 22. ed., London, Butterwoth, 1980, apud Adolfo di Majo, La tutela civile dei diritui, Milano, Giuffrè, $1987, \mathrm{p} . \mathrm{V}$, no direito anglo-saxão, porérn, fala-se em "remedies" para a tutela dos direitos.

35. Basta atentar nesta passagem: "A pretensão à tutela jurídica não é pretensão à sentença "favorável", e aj tem razão Oskar Bülow; mas, simplesmente, à senterkça ou à execução. Por isso mesno temos de afastar qualquer concepção que construa a pretensão à tutela juridica como pretensăo à sentença favorável" (Pontes de Miranda, Tratado das Açôes, tomo I, cit, p. 172). Tratáse, na verdade, daquilo que a doutrina alemä atual denomina de "pretensão à outorga de justiça", tema ao qual retornarei no decorrer da exposição.

${ }^{56}$ Pontes de Miranda, Tratado das Ações, tomo I, cit., p. 33. Refere-se à ação de direjto material, porque sem aspas e como se extrai do contexto. Eun 1934 não falava de pretensão, só de ação de direito material, e a existência do direito era sempte necessária. Agora não, o direito material pode não existír, o que está en contradiçäo com a assertiva de que "a ação supöe haver-se transgredido a norma".

${ }^{57}$ Pontes de Miranda, Tratado das Açóes, cit., p. 116.

š Pontes de Miranda, Tratado das $A$ fóes, cit., p. 110.

${ }^{59}$ Pontes de Miranda, Tratado das $A$ çöes, cit., p. 33.

"ro Pontes de Miranda, Tratado das $A$ çôes, cit, p.34, aqui já não há referência à ação de direito material. 
se vinculou, e exerce-se, com o remédio juridico processual adequado, a ação de direito material" "1. Se o autor não tinha a ação (de direito material), "exerceu pretensão à tutela jurídica, exerceu a pretensão ao remédio jurídico processual, porque não podia esperar sentença favorável quanto à ação de que se supunha ser titular" ${ }^{62}$.

Também a pretensão de direito material e a ação de direito material existem antes do processo. A pretensão invocada "pertence ao corpo mesmo do direito material, é intrínseca ao direito, que a tem, e os direitos que não a têm só não a tem porque eles mesmos foram nascidos sem ela, ou a regra objetiva a fez precluir ou prescrever. É ponto que merece toda atenção: a pretensão invocada é instituto do direito material, e não do direito formal ou processual" 63.

Todavia, o conceito de pretensão material de Pontes de Miranda não se deixa apanhar facilmente. Critica a definição de pretensão realizada pelo $\$ 194$ do Código Civil alemão ${ }^{64}$, que considera infeliz, porque limita o conceito às prestações de fazer e não fazer, deixando de fora as ações declarativas e constitutivas, em que o fim do litigante não consiste em algum fazer ou não-fazer. Além disso, exibe pouca consistência sustentar que "A pretensão nasce, ainda que nasça sem a exigibilidade de pessoa a pessoa. Mas, se há ação e o titular do direito é o mesmo da ação, a ação, aí, é o que resta da pretensão" "S. Na verdade, nos exemplos formulados o conceito de pretensão reduziu-se a um mero flatus vocis e não haveria nenhuma razão para continuar insistindo na sua existência ". Exigir pela "ação", como se pretende, é confundir simplesmente a pretensão com a ação ptocessual. Nota-se claramente que, ao buscar justificar a existência da pretensão de direito material na ação declaratória ${ }^{67}$, Pontes de Miranda confunde elementos de direito público (exigência de tutela jurídica do Estado) com elementos de direito privado (ação de direito material, direito subjetivo). Mais adiante, porém, não pode deixar de reconhecer que "O exercer pretensão, ou ação, ou exceção, que se contém no direito, é exetcer o direito", poder que faz parte do direito, poder de revelar (exprimir, enunciat) a própria existência ${ }^{68}$. Para ele tão rente está ao direiro material a ação de

"Pontes de Miranda, Tratado das Açôes, cit., p. 94-95.

62 Pontes de Miranda, Tratado das Açôes, cit., p. 95.

6.3 Pontes de Miranda, Tratado das Açũes, cit., p. 36. Constata-se, na comparação com o texto de $1934, A$ Aç̧ão Rescisória contra as Sentenças, cit., $\$ 3,5$, p. 17, que o conceito de pretensão material veio a substituir nesse contexto a ação de direito material.

(it Está assim redigida a 1". parte do $\$ 194$ do BGB, que trata do objeto da prescrição: "Das Recht, von einnem andere ein Tun oder ein Unterlassen zu verlangen (Asnpruch)", ou seja, a pretensão é o direito de exigir de outrem um fazer ou um näo-fazer.

65 Pontes de Miranda, Tratado das Açôes, cit., p. 44-45.

ك6 A respeito do conceito de pretensão, observa acertadamente G. Pugliese, Polemica, cit., p. XXXIXXXIV, que o seu exercício näo se mostra relevante para o direito subjetivo, pois nada the acrescenta. O que interessa é saber como o citular pode obter da contraparte o comportamento a que esta estava obrigada. Tudo se resume à ação en juizo, nos modos previstos em lei.

67 Pontes de Miranda, Tratado das Af̧öes, cit.,p. 46-47.

${ }^{68}$ Pontes de Miranda, Tratado das Ações, cit., p. 67. 
direito material e a pretensão material que só podem ser exercidas nos limites do seu conteúdo ${ }^{69}$, conceito que pode servir, quando muito, ao plano do direito material, mas não ao plano do direito processual, que é o reino da incerteza e da dúvida. Por exceção, afirma Pontes de Miranda, a ação pode existir sem a pretensão (ou sen o resto da pretensão), tal como ocorre com os direitos formativos, sejam geradores, modificativos ou extintivos ${ }^{70}$.

Visto que, no fundo, a teoria empresta maior realce aos fatores materiais que aos processuais, o conceito de ação processual não aparece com nitidez nas elaborações doutrinárias do grande mestre. Oraé equiparada, como se viu, a remédio jurídico processual, apresentandose assim mais como um elemento passivo do que ativo, que não se compadece com a dinamicidade do fenômeno processual. Ora é equiparada à demanda ou à lide, e conceituada como "negócio jurídico com o qual o autor põe o juiz na obrigação de resolver a questão, ainda que seja "se cabe a contestação, ou o mandamento, ou a execução". À base da legitimação para esse negócio jurídico estão a capacidade de ser parte e a pretensão à tutela jurídica (uma e outta pré-processuais). Da demanda é que surge o dever concreto de resolver; o de dar sentença favorável é dependente de ser fundada ("procedente") a ação ${ }^{71}$.

Como se vê, homem de seu tempo, preso às suas raízes culturais e à doutrina alemã, Pontes de Miranda tetoma o conceito de pretensão de Windscheid, de certa forma semelhante ao de Savigny, e the empresta a denominação de ação de direito material. Adiciona ao esquema a ação abstrata, tal como esboçada por Muther, e como já o fizera o próprio Windscheid. Nesse quadro, totalmente concretista, proclamou, contudo, na linha de Plósz e de Degenkolb, que o autor não teria direito a uma sentença favorável, mas apenas a uma sentença de qualquer conteúdo, que se presume justa. Por isso mesmo, não consegue se desvencilhar da expressão cunhada por Wach, embora empregue o conceito de pretensão à tutela jurídica, en sentido totalmente diverso, como antes ressaltado. Demais disso, embora não confesse, faz o conceito de ação de direito material desempenhar o mesmo papel do direito justicial material de Golschmidt. Este, recorde-se, não só colocava a acionabilidade do direito na norma jurídica material, como também conceituava o direito justicial material como direito marerial privado orientado conrra o Estado.

Basicamente na mesma linha de pensamento situa-se Ovídio A. Baptista da Silva ${ }^{72}$. Para ele, igualmente, convivem a ação e a "ação". A ação de direito material cotresponde "ao agir contra o obrigado para a realização do direito, independentemente de sua colaboração". A "ação" (processual) é "dirigida contra o Estado, para que ele, provocado pelo interessado (autor), exerça a atividade jurisdicional a que se obrigou e preste a respectiva tutela, dando resposta adequada ao pedido". A ação de direito material "tem como pressuposto um

69 Pontes de Miranda, Tratado das A fões, cit., p. 69.

${ }^{70}$ Pontes de Miranda, Tratado das Açóes, cir., P.115.

7 Pontes de Miranda, Comentários ao Código de Processo Civil, tomo I, Rio de Janeiro, Forense, 1974, p. XXIVXXV.

${ }^{72}$ Ovídio A. Baptista da Silva, Curso de Direito Processual Civil, vol. I, 5ª ed., São Raulo, RT, 2000, p. 93-93. 
direito material preexistente de que é titular sempre aqquele que age, esta a "ação" processual, por força há de estar igualmente fundada num direito anterior. Também ela, como qualquer outra atividade lícita, deve corresponder a um direito exigível (=pretensão), sob pena de configurar o puro arbítrio e a violência". Em outra passagem, consigna o jurista"s " "A realização coativa do direito, com absoluta prescindência da vontade ou da colaboração do obrigado, que se consegue através da junisdição, é rigorosamente a mesma ação de direito material, ou seja, o mesmo agir para a realização inerente a todo o direito, com a única diferença que, proibida a autotutela privada, a efetivação do direito se dá através da ação dos órgãos estatais. Portanto, longe de haver supressão ou substituição da ação de direito material, o que em verdade ocorreu foi uma duplicação de ações: uma dirigida contra o obrigado, outra endereçada contra o Estado, para que este, uma vez certificada a existência do direito, o realize coativamente, praticando a mesma atividade de que fora impedido seu titular".

No que concerne à ação processual, apresentaria três faces. De um lado, a "ação" éo exercício do direito de acesso aos tribunais, do qual constitui um prius lógico; de outro, éo agir do próprio autor para a obtenção da tutela jurisdicional; finalmente, é também o exigir que o Estado aja, prestando tutela jurídica ${ }^{7 / 4}$.

Realizada essa longa e necessária introdução impõe-se indagar se esse amálgama de conceitos conflitantes resiste a uma análise crítica. A teoria continuaria consistente e intocável, em face do influxo das elaborações doutrinárias posteriores a respeito das relações de direito público, que regulam a funç̧ão jurisdicional, eàs exigências mais modernas de efetividade? $\mathrm{E}$ o que procurarei examinar nos tópicos que seguem.

4. Em primeito lugar, a perspectiva de que o resultado final do processo equivale à ação material que seria desenvolvida pela parte fora do processo ignora, no fundo, a função exercida pelo juiz no processo, fruto do monopólio estatal da prestação jurisdicional e dos desenvolvimentos granjeados pelo direito público e constitucional.

Como bem pondera Liebman, não há dúvida de que o processo é instrumento de realização do direito material, mas tal finalidade é alcançada por meio do agir do Estado, que assegura a efetiva vigência da ordem jurídica. A essência da ação encontra-se exatamente na relação que se estabelece no ordenamento jurídico entre a iniciativa do indivíduo e o exetcício, em concreto, da jurisdição, vale dizer, na necessidade e na eficácia da invocação ao juiz para que "proceda"; e pertence à essência do processo que o juiz deve determinar, segundo as normas que regulam a sua atividade, o conteúdo positivo ou negativo da sua decisão final ${ }^{75}$. Embora

${ }^{23}$ Ovidio A. Baptista da Silva, Curso de Direito Processual Civil, vol, II, 4. ed., São Paulo, RT, 2000, p. 84-85.

${ }^{74}$ Ovidio A. Baptista da Silva, Carro de Direito Processual Civil, vol. I, cit, p. 87, 89 e 93.

${ }_{75}$ Liebman, $L$ 'azione nella teoria del processo civile, in Problemi del Processo Civile, Napoli, ed. Morano, 1962, p. 3031, e acentua: "Quem prescinde desses dois aspectos do problema arrisca-se a construir um conceito de ação no qual está ausente a ação e uma teoria do processo na qual é ignorado o processo". 
verdadeiro que a ação tende a produzir um determinado efeito jurídico a cargo da contraparte, esse efeito derivará da decisão do juiz e, assim, a ação, enquanto direito, tem por objeto imediato aquela decisão, dirigindo-se contra quem pode e deve emaná-la, isto é, o juiz, na sua qualidade de órgão do Estado ${ }^{76}$.

Ressalta ainda Liebman, com base em conhecido ensinamento de Carnelutti, depois adotado por Betti, que "A ação é, portanto, um direito ao meio, não ao fim, e isto em dois sentidos diversos, tanto no que se refere ao seu conteúdo quanto no que se refere a sua diteção, que constituem, pois, dois aspectos de uma única telação" "77. Conceber o direito do individuo diretamente contra o adversátio, prossegue, incluindo ai o resultado da atividade esratal, significa de novo colocar o fim no lugar do meio e ptetender absorver no direito privado uma quantidade de todo estranha e de natureza profundamente diversa, como é induvidosamente o exercício de um poder de direito público, pertencente a título originário aos órgãos da soberania do Estado ${ }^{78}$.

Nem procede o argumento de que o conceito de ação de direito material constituiria a melhor maneira de tornar mais eficaz e efetiva a realização do direito subjetivo privado. Como ainda aqui sustenta Liebman, "A defesa mais eficaz do direito subjetivo privado não consiste em fechá-lo dentro de sua trincheira, onde é condenado a permanecer inerte, mas, sim, em afirmar-se a intangibilidade da arma que o direito público põe a sua disposição; e essa arma é a ação, porque apenas ela constitui o meio idôneo para lutar no campo aberto do processo, em contato direto com os órgãos do Estado" 7".

E menciona Carnelutti, cujo ensinamento por sua pertinência ao tema vale a pena reproduzir. A confusão entre ação de direito material e direito subjetivo decorre, sem dúvida, de um erro de perspectiva que ignota a telação de meio a fim entre os dois direitos. A ação serve para a tutela do direito material, mas não se confunde com o direito que se prerende seja atendido em juízo. A concepção privatística do processo, da mesma maneira que levou o sistema a gravitar inteiramente sobre o direito subjetivo, induziu também à crença de que este não era outra coisa senão o direito exercido em juízo. Pouco a pouco, porém, por meio de uma série de tentativas, alcançou-se a separação: cumprindo esclarecer que uma coisa é o direito exercido em juízo (id est correspondente à pretensão) e outra o direito de obter que o ofício proveja sobre a pretensão, e dessa forma se separatam por sua vez o direito subjetivo material e o direito subjetivo processual ${ }^{\text {gn }}$.

${ }^{76}$ Liebman, $L$ 'azione, cit, p. 31 .

${ }_{i}$ Liebman, $L$ 'azione, cit., p. 31 e nota 15.

${ }^{78}$ Liebrnan, L'azione, cit., p. 32.

"s Liebman, $L$ 'azione, cit, p. 50.

${ }^{80}$ Carnclutti, Sistema, cit., $\mathrm{n}^{\circ} 356$, p. 889-890, que observa ainda: "Năo haveria razão para negar a este últino (o direito subjetivo processual) o antigo nome de ação, zo qual, pottanto, a moderna ciência do processo restitul seu genuíno significado; por outra parte, no direito moderno a ação existe, na maior parte dos casos; junto ao direito subjetivo material e não no lugar deste" (grifos do original). A duplicação 
A verdade é que, negadas as concepções monistas do direito, ponto atualmente pacífico, mostra-se forçoso reconhecer a autonomia do processo em relação ao direito material, nada obstante a íntima conexidade entre os planos material e processual. Ademais, com o monopólio estatal da administração da justiça, a ação só pode ser pensada como um poder dirigido contra o Estado, pois só esse pode garantir a tutela jurisdicional dos direitos e determinar os pressupostos pelos quais deve ela ser outorgada. Não se cuida, portanto, de um direito privado, mas de um direito revestido de natureza pública, que por seu caráter, sua direção, seù conteúdo e seus requisitos se distingue essencialmente da pretensão privada. Um dos erros de Thon, além de negar ao direito subjetivo sua realização fora do processo, foi colocar no direito subjetivo privado a coercibilidade estatal. Equívoco este também perfilhado por Pontes de Miranda e seus seguidores. $O$ direito subjetivo exibe realmente essa potencialidade. Cuida-se, no entanto de elemento ligado ao direito público e não ao privado a ser exercido pela ação (processual), cuja realizabilidade, em face do não cumprimento voluntário, dá-se no plano jurisdicional (salvo poucas exceções). Daí, a exata conceituação de P. Roubier: direitos subjetivos são prerrogativas vantajosas estabelecidas pelo direito objetivo, munidas de proteção judicial ${ }^{8 !}$.

Realmente, hoje está bem claro que a garantia do acesso à justiça impõe ao órgão judicial o dever de exercer jurisdição. Daî terem as partes direito à pretensão de outorga de jus tiça (Anspruch auf Justizgewäbrung ou Justizanspruch), dirigida contra o Estado como titular da soberania, por meio de um processo efetivo e justo ${ }^{82}$. De modo nenhum se cuida de simples efeito reflexo do direito objetivo, visto que o dever do Estado de outorgar juris dição habita não apenas no interesse geral, mas especialmente no do interessado, que busca a satisfação de seu direito perante o órgão judicial. Demais disso, a outorga de justiça não fica

de ações, uma de direito material, outra processual, ao fin e ao cabo, bem doutrina E. Fazzalari, Sentenza civile, in Enciclopedia del Diritto 51(1989):1.245-1.272, esp. p. 1.252, acaba por repropor a antiga idéia de Anspruch (pretensão), que Windscheid queria identificar com uma actio substancial e distinguir da açào em sentido processual, mas que Muther já tejeitava como uma inaceitável superfetação da realidade processual.

B1 Paul Roubier, Droits subjectifset situations juridiques, Paris, Dalloz, 1963, p. 1-2, 35-39, 129, passim. A respeito do conceito atual de direito subjetivo ver ainda as preciosas considerações de Cláudia Toledo, Direito Adquirido e Estado Democrático de Direito, Sào Paulo, Landy, 2003, passim, com ampla análise do desenvolvimento fliosófico da idéia de Justiça e Direito realizado por Henrique Cláudio de Lima Vaz e Joaquim Carlos Salgado. Betn ressalta esta autora (ob. cit, p. 105), com base no ensinamento de Baracho, que os direitos valem por si sós, porquie sầo bens do sujeito, as gataruias têm valor instrumental e derivado, e arremata cheia de razão que se reportam ao Estado, ao Poder Judiciário, para sua concreção. Antes desenvolvera o conceito de irresistibilidade do direito subjetivo, que compreende o de coercibilidade (possibilidade do uso da força física aparelhada do Estado), concretizando a ação judicial, considerada força irresistivel do Direito (ob. cit., p. 44).

${ }^{12}$ F. Baur, Der Anspruch auf rechtliches Gebör, in Beiträge zur Gerichtsvenfassung und zum Zivilprozessrecht, Tübingen, J.C.B. Mohr (Paul Siebeck), 1983, p. 86-87, Rosenberg/Schwab/Gotrwald, Zivilprozessrecht, 16. Auflage, München, Veriag C. H. Beck, 2004, \$3; 1, 2, p. 17. 
ao arbitrio do órgão judicial, e é vista pelo contrário como uma proteção imperativa e não meramente aleatória. Por isso se caracteriza, fora de qualquer dúvida, como um direito subjetivo público ${ }^{83}$, enquadrando-se mais precisamente na categoria dos direitos fundamentais, hoje constitucionalizados. Esse direito fundamental se concretiza, no plano processual, com o exercício da ação (processual, bem entendido), que decorre dos poderes e faculdades da parte autora, iniciando-se con a demanda e prosseguindo ao longo de todo o procedimento, por meio de atos concretos. Quando concedido o provimento final, seja ato executivo ou sentencial, a ação (processual) já terá sido exercida plenamente em sua integralidade, seja qual for o resultado do processo, o que afasta qualquer idéia de concretude.

Aliás, visto ò problema na perspectiva do resultado da tutela jurisdicional, considerado o caráter eminentemente publicístico da jurisdição e do processo, o comando daí resultante projeta a sua efićácia no patrimônio das partes por força própria, em razão da soberania do Estado-juiz, e não certamente em virtude de uma norma de direito privado ${ }^{84}$. O direito material, note-se bem, é para o juiz apenas a norma de resolução, a determinar o conteúdo da sentença de mérito. Naturalmente, quem põe na penumbra o império contido no exercício da funçâo jurisdicional tende a ver nas sentenças declarativas, condenatórias ou constitutivas só declaração, só pensamento, só norma, abstraindo a eficácia substancial contida no comando judicial. Todavia, adotada uma visão totalizante do fenômeno jurídico, a englobar fato, valor e norma, a declaração é também efeito jurídico, com conseqüências práticas. Embora não interfira diretamente no plano sensivel, determina o comportamento que devem as partes adotar para o futuro (por isso, v.g., a possibilidade de antecipar-se o pedido de sustação de protesto cambial, no bojo de demanda declarativa negativa de relação jurídica creditícia).

Claro que posso denominar a força realizadora do direito material de ação de direito material. Todavia, o problema não é meramente terminológico. O conceito mesmo de ação de direito material, de caráter eminentemente privado, é que não resiste a um exame lógico e sistemático, quando posto em confronto com o sistema processual, de cunho eminentemente público e constitucional.

Antes de nada, a ação de direito material, que seria exercida conjuntamente com a ação processual, pressupõe a existência do direito material, porque é a inflamação do direito

8.3 Teichiro Nakano, Das Prozessrechtsverhältnis, in Zeitschrift für Zivilprozess, 79(1966):108.

${ }^{84}$ Cf. Elio Fazzalari, La dottrina processualistica italiana: dall "azione" al "processo"(1864-1994), in Rivista di Diritto Processuale, 1994, p. 924, ressaltando que "não por nada o conceito de "processo" se concentra na participação, em contraditório, dos destinatários dos efeitos substantivos que o provimento do juiz é festinado a produzir". E acrescenta o jurista italiano: "De resto, mesmo a se entender - como muitos ainda fazem, com inspiração num pensamento antigo e antiquado, e contra a evidencia - que o provimento jurisdicional teria natureza de "declaração" (accertamento) e não de "comando", a sua eficácia substantiva seria sempre assistida pelo império do juiz, e não haveria certamente necessidade de uma intromissão do direito privado". 
material ou da pretensão ${ }^{85}$, ou o próprio direito subjetivo reagindo contra a agressão que the foi feita ${ }^{86}$. Ora, se não é possivel reconhecer a existência do direito antes do contraditório, fica difícil admitir a "ação de direito material", já no inicio da demanda, algo que está ínsito ao próprio direito subjetivo, que faz parte da sua essência. Se é da essência do direito, o agir para sua integral realização, representando a ação de direito material a inflamação do direito depois da lesão (a "metamorfose" de Savigny), a sentença haveria de ser sempre favorável, porquanto a demanda pressuporia por hipótese a existência do direito. Não padece dúvida, no entanto, em razão da própria incerteza consubstancial do direito litigioso ${ }^{87}$, que sua existência só poderá ser averiguada ao final do processo, com o trânsito em julgado da sentença. Com a sentença de improcedência da demanda ter-se-á declarado a inexistência tanto do direito material quanto da própria ação de direito material, fenômeno que se pretende ínsito ao direito material!

Para afastar-se essa evidente incongruência, passa-se a sustentar que aquilo que é algo consubstancial ao direito subjetivo, integrante da sua própria essência, não é tão substancial assim, constituindo quando ingressa no processo mera realidade afirmada ${ }^{88}$. Ora, se a ação de direito material é algo imanente ao direito material, o seu exercício pressupõe uma sentença favorável. Não bastasse isso, a explicação incorre em outra contradição. A simples afirmação da ação, enquanto ato que se esgota em si mesmo, no afirmar, revela-se totalmente incompatível com o conceito de ação, mormente com a "ação exercida", que por hipótese pressupõe um agir em determinada direção, exercício do poder (ou do direito) de agir. Se ajo não afirmo, se afirmo, quedo-me no simples plano do verbo, do dizer, e não ajo. Tertium non datur.

Por outro ângulo visual, o autor não afirma a existência da ação de direito material, mas do direito e da lesão, e com base nisso pede a adoção da tutela jurisdicional que entende

${ }^{85}$ Pontes de Miranda, Pontes de Miranda, Tratado das Ações, cit., I, p. 19.

${ }^{\text {Bá }}$ É a última formulação de Ovídio A. Baptista da Silva, Dirgito Material e Processo, in Gênesis - Revista de Direito Processual Civil 33(jul-set/2004):615-635, esp. p. 618: "Mas o interesse na concepção do "direito subjetivo" oferecida por Thon vai além. Segundo ele, o direito subjetivo corresponderia à faculdade de iniciativa que a ordem jurídica confete ao "sujeito tutelado" para, em caso de transgressão da norma, realizar o que fora por ela originariamente determinado. O conceito de direito subjetivo, assim defrinido, equivale ao que entendo por "ação de direito material". A faculdade que temos de "reagir contra a agressão ao direito" é uma ação, posto que "ajo", não apenas um direito subjetivo, que ainda se mantenha como puro status". No Curso de Direito Processual Civil, vol. II, cit., p. 354-355, essa identidade ressaita ainda com mais força, pois ai a "açăo de direito material" é conceiruada como "o agir próprio de cada direito, capaz - independentemente de qualquer paricipação ativa do obrigado - de realizar inteiramente o respectivo direito".

${ }^{87}$ A respeito da incerteza do direito litigioso, Caflos Alberto Alvaro de Oliveira, Alienação da Coisa Litigiosa, 2*. ed., Rio de Janeiro, Forense, 1986, p. 53 -55 (1*.. ed., 1984, p. 51-54).

${ }_{88}$ Assim, Ovidio A. Baptista da Silva, Direito Material e Processo, cit., p. 627: "A "açăo exercida", a que PONTES DE MIRANDA se referia, não passava de uma simples "afirmação" feita pelo autor que "alegava" ter pretensão, eri ultima análise de ter "direito exigivel" (rectius, pretensẫo". 
adequada ${ }^{89}$. Desse modo, o direito material torna-se componente da situação que legitima tanto os atos da parte quanto os do juiz, podendo-se colher vários graus de tal coordenação (entre os atos do processo e o direito), passando-se da asserção do direito, que legitima os atos preparatórios das partes e do juiz no processo de conhecimento, à colheita da prova, de que constitui objeto, e à declaração do direito, que legitima no processo de conhecimento, a sentença de acolhimento e, no processo de execução, toda a sétie procedimental ${ }^{10}$. Além disso, não se trata propriamente de afirmar a existência da tutela jurisdicional (ou da ação de direito material), mas de demonstrar sua adequação à lesão e ao direito, ambos afir mados in status assertionis.

Não bastasse isso, analisadas as vicissitudes da "afirmação" da ação de direito material, constata-se que ela não passa de um mero "slogann", uma idéia que não chega a ter existência real. Depois de afirmada - e não exercida, ao contrário do que se apregoa, porque obviamente a firmação não se exerce —, o agir é realizado exclusivamente por meio da ação processual, pelo exercicio das faculdades e poderes da parte, que se concretizam em atos processuais, conforme a seqüência procedimental estabelecida em lei (v.g., demanda, réplica, pedido de prova, arrazoados, recursos etc.). Além disso, depois de decidido o litígio, também não reaparece a ação de direito material, porque a eficácia e a força da sentença decorrem do comando emitido pelo órgão judicial, que recai na esfera substancial das partes, em virtude do império decorrente do exercício da jurisdição e da soberania do Estado. Não custa lembrar que as normas reguladoras do processo, geralmente de direito público, dirigidas especialmente à função jurisdicional, não se preocupan diretamente com o direito material pretendido, e ao mesmo tempo o sujeito da conduta prevista na norma de direito material certanente não é o órgão judicial. O juiz não age, exerce atos de seu oficio, que podem conduzit a transformações no mundo sensível, mediante o exercício dos poderes que the são conferidos por regras de

"Como bem sustenta Francesco P. Luiso, Diritto Processtale Civile, vol. I, cit., P. 7, "La tutela giurisdizionale trova dunque il suo punto di partenza in una realtà di diritto sostanziale che si puo descrivere nei seguinte termini: un soggetto avrebbe dovuto tenere o non tenere un certo comportamento, secondo le prescrizioni normative; invece, in concreto, il comportamento non è stato tenuto laddove era obbligatorio tenerlo, o viceversa è stato tenuto laddove era vietato tenerlo. Il pressuposto costante della tutela giurisdizionali, quindi, può essere trovato nell'esistenza di un illecito, intendendo per illecito il concreto comportamento difforme dal dovere imposto da urna previsione normativa. Questo è il pressuposto comune a tutta l'áttivita giurisdizionale; ma, per quanto attiene all'attività giurisdizionale civile, c’é un quid pluris, cui abbiano già accennato: la violazione del dovere, cioè l'illecito, produce anche la lesione, l'insoddisfazione di uma situazione sostanziale protetta. L'illecito provoca (anche) la violazione di quell'interesse protetto ed elevato dall'ordinamento a dignita di situazione sostanziale, per la cui realizzazione appunto l'ordinamento aveva previsto il dovere che é stato violato".

90) Cf. Fazzallari, Note, cit., p. 110-161. 
direito público, totalmente distintas das regras de direito privado ${ }^{91}$. Assim, a alegada ação de direito material, urna vez julgada procedente a demanda, passa a se confundir com o resultado do processo, ou com a tutela jurisdicional dispensada pelo Estado. De tal sorte, no quadro da realização do direito material, a inrrodução do conceito de ação material constitui um desnecessário desdobramento do conceito de ação processual, como desde muito está assentado na ciência processual.

A esse respeito, revela-se altamente significativa a aguda crítica de Couture à doutrina de Pontes de Miranda, que merece ser reproduzida in verbis ${ }^{92}$ :

"Se ha dicho, entonces, que la doctrina que configura la acción como un derecho genérico de obrar confunde aquélla, la acción, con el derecho de demandar, que es un derecho diferente. Conviene no dejar en pie este argumento. Si la acción y el derecho a demandar son dos poderes jurídicos diferentes, entonces tendriamos tres órbitas del derecho: lo que llamamos derecho material (p. ej., la propriedad), la acción (p. ej., la reivindicación) y el derecho a demandar en juicio (p. ej., la facultad de interponer la demanda reivindicatótia). Pero desde nuestro ponto de vista, las cosas non son así. El derecho de demandar (rectius: el derecho a promover y llevar adelante el proceso) es, justamente, la acción. Todo sujeto de derecho tiene, como tal, junto con sus derechos que llamamos, por comodidad de expressión, materiales o sustanciales (en el ejemplo, la propriedad), su poder jurídico de acudir a la jurisdicción. Denominamos acción a este poder jurídico, y el derecho de demandar no es sino el ejercicio concreto del derecho de acudir a la jurisdicción, ya que el proceso civil se halla regido por la máxima nemo judex sine actore. La acción civil se hace efectiva mediante una demanda en sentido formal, y ésta no es sino el ejercicio de aquélla. No creemos que quede, dentro de la estructura del derecho, luego de haber distinguido entre el detecho material y el derecho procesal de acción, sitio para un tercer derecho, que no sería otra cosa que la acción puesta en ejercicio. Un tercer poder jurídico intermedio, entre el derecho material y el derecho procesal, ya sea que se incluya en cl primeiro, ya sea que se incluya en el segundo, constituye un innecesario desdoblamiento".

- De tal modo já havia me manifestado a respeito do assunto en ensaio anterior, O problema da eficácia da senteņ̧a, Repro, 112(out.-dez./2003):9-22, esp. p. 18, aduzindo ainda que "Só depois de tomada a decisão (seja antecipatória, seja a própria sentença de mérito) é que o juiz pode em tese interferir no mundo sensivel, agindo, mas aí já se trata do resultado da tutela jurisdicional, da própria eficácia da sentença. Antes disso, como é óbvio, não teria havido ação de direito material. Mesmo assim, esse agir dio juiz não pode ser equiparado, purà e simplesmente, ao agir do particular, dada a natureza diferenciada da tutela jurisdicional e a forma substitutiva de que se reveste, destinada a reconstruir a realidacte fora do processo e não apenas a reproduzina”.

92 Couture, Fundamentos del Derecho Procesal Civil, $3^{\mathrm{a}}$ ed. (póstuma), Buenos Aires, Depalma, 1973, $\mathrm{n}^{\circ} 44$, p. $73-74$. 
Por outro lado, segundo seus defensores, a ação de direito material, por constituir ex bypothesis parte integrante do direito subjetivo material, deve se dirigir necessariamente contra o adversário, enquanto a ação processual é endereçada contra o Estado ${ }^{933}$.

A proposição, porém, revela-se inadmissível, porque o autor ao pleitear tutela jurídica nada pede ao demandado, mas ao órgão judicial, e o que ele pede não the pode ser concedido pelo demandado, mesmo que por este querido. Por isso, a pretensão de tutela jurídica não é idêntica ao direito material ${ }^{94}$.

Essa última constatação conduz, por sinal, a urna outra objeção de peso contra o conceito de ação de direito tnaterial. As chamadas açòes de direito material (declaratórias, condenatórias, constitutivas, mandamentais e executivas) não têm existência mesmo antes do processo. Não só em razão do monopólio estatal da administração da justiça, mas principalmente porque os pronunciamentos judiciais e as sentenças, seja qual for o seu conteúdo (declaratório, constitutivo, condenatório, mandamental ou executivo), não passam de formas próprias e exclusivas da tutela jurisdicional ${ }^{95}$. Constituem meios, de que se serve 0 Estado, para prestar justiça e realizar o direito material da maneira mais adequada e efetiva, verdadeiras técnicas, que idealmente devem servir aos fins últimos do processo e à realização do direito material. Ora, se se cuida de técnica, não há como confundi-las com o direito material ou com uma faceta deste ${ }^{\% /}$, porquanto o direito, enquanto sistema de atribuição de

"3 A respeito, assim se expressa Ovídio A. Baptista da Silva, Curso de Direito Processual Civil, tomo I, cit., p. 84 85 (grifos do original): "A realizaçăo coativa do díreito, com absoluta prescindência da vontade ou da colaboração do obrigado, que se consegue através da jutisdição, é rigorosamente a mesma ação de direito material, ou seja, o mesmo agir para a realização inerente a todo djreito, com a única diferença que, proibida a autotutela privada, a efetivaçăo do direito se dá através da af̧ão dos órgãos estatais. Portanto, longe de haver supressäo, ou substituição, da ação de direito material, o que em verdade ocorreu foi uma duplicação de ações: uma dirigida contra o obrigado, outra endereçada contra o Estado, para que este, uma vez "certificada" a existencia do direito, o realize coativamente, praticando a mesma atividade de que fora impedido seu titular.".

2. Cf. Othmar Jacumig, Zivilprozessrecht, 21. Auflage, Beck, München, 1985, \$36, I, 2, p. 127: "Isr ist kein Anspruch gegen den privaten Gegner, die Gegenpartei, sondern ein Anspruch gegen den im Gericht verkörperten Staat. Der Kläger, welcher Rechtsschutz begehrt, verlangt damit nichts vom Beklagten, sondern vom Gericht, und das, was er begehrt, kann ilum der Beklagte nicht geben, selbst wenn er es wollte. Daher is: dex Rechtsschutzanspruch nicht dem materiellen Rech identisch".

95 Embora não declare abettamente, parece se colocar na mesma senda Luiz Guilherme Marinoni, Técnica Processual e Tutela dos Direitos, Säo Paulo, RT, 2004, p. 145-147, quando acertadamente sustenta que as sentenças (condenatória, mandamental etc.) e os meios de exccução são apenas técnicas para uma adequada prestação jurisdicional. Alís, já em obra anterior (Do Formalismo no Processo Civil, 2a. ed., São Paulo, Saraiva, 2003, p. 125), havia eu ressaltado que a tarefa da técnica jutídica consiste em formar a sintese entre o sistema e a forma, apresentando-se como meio para compor ou executar, com certa eficácia e proveito, os imperativos da parte normativa do direito.

96 Não esquecer que, para seus cultores, a ação de direito material constitui parte integrante e indissociável do direito material. Mesmo assin, diante da realidade, vez e outra admitem estes a inexistència da ação de direito material. Assim, quanto à tutela declaratória, Pontes de Miranda, Tratado das Ações, tomo I, cit., p. 197; no que concerne à tutela condenatória e a certas espécies de tutela mandamental, Ovídio A. Baptista da Silva, Curso, cit, vol. II, p. 354:355, p. 204. 
bens e organização social, não é uma técnica, mas a positivação do poder, ou seja o conjunto de normas em que transparecem as decisões do Estado (centro de poder), destinadas a orientar a conduta das pessoas e suas relações em sociedade ${ }^{37}$. Por isso mesmo, embora as diversas espécies de tutela jurisdicional sofram forte influência do plano do direito material com ele rão se confundem. Uma coisa é, por exemplo, desfazer, anular, cancelar, distratar, reconhecer dívida, transigir, admitir na função pública, restituir ou reparar (plano do direito material), outra totalmente distinta é condenar, mandar, declarar, constituir ou executar (plano da tutela jurisdicional). Esses últimos verbos, num Estado minimamente evolúdo e com instituições já desenvolvidas, só podem decorrer da atividade de um terceiro imparcial, investido de império bastante para ter força e legitimidade suficientes, elementos esses capazes de impor o resultado da tutela jurisdicional e sua aceitação pelos interessados. Por tais motivos, a regulação dessa atividade está afeita a notmas de direito público e constitucionais, pouco ou minimamente interferindo nessa seara o direito privado, De tal sorte, o direito processual pode ou não permitir a demanda declaratória depois de consumada a lesão, o sistema constitucional pode tornar lícito o emprego da tutela mandamental ou executiva $\mathrm{e}$ assim por diante. Interessante, a esse respeito, é a norma contida no $\$ 35$ da lei que regula a atividade do Tribunal Federal Constitucional alemão, permitindo-the, além de determinar em sua decisão quem a executará, a regulação no caso concreto da espécie e da forma da sua execução $\%$.

Na verdade, não se pode confundir o apêndice inflamado, a doença (o direito lesado), com o bisturi destinado a extirpá-lo, o remédio (a tutela jurisdicional), nem com a extirpação exitosa, a cura (a tutela do direito). Trata-se de realidades distintas, embora vinculadas umas a outras, sofrendo portanto influências recíprocas. Tudo isso, é claro, desenvolvendo-se por meio dos diversos atos do cirurgião, dos enfermeiros e demais auxiliares (atos processuais do juiz, das partes, do escrivão, do perito etc. que, em suma, compõem o procedimento e por extensão o processo).

Chama a atenção, aliás, que Pontes de Miranda ao ter proclamado que a sentença mandamental constituiria ato necessariamente estatal, exclusivo assim do juiz, não representando atividade substitutiva daquela do particular ${ }^{99}$, não se tenha dado conta da

${ }^{7}$ Cândido R. Dinamarco, $A$ instrumentalidade do processo, 10². ed., São Paulo, Malheiros, 2001, p. 274.

${ }^{9}$ Bundesverfassungsgerichtsgesetz - $\mathrm{BVerfGG}$, de 11.8.1993, com as alterações da lei de 16.7.1998, $\$ 35$ "(Regelung der Vollstreckung) - Das Bundesverfassungsgericht kann in seiner Bntscheidung bestimmen, wer sie vollstreckt; es kann auch im Einzelfall die Art und Weise der Vollstreckung regeln".

19) Pontes de Miranda, Tratado das Açôes, tomo I, cit., p. 211, ao cuidar de estabelecer o conceito de sentença mandamental, ressalta a essencialidade do mandado, afimando que "No mandado, o ato é ato que só o juiz pode praticar, por sua estatalidade. Na execução, há mandados - no correr do processo; mas a solução frrial é ato da parte (solver o débito). Ou do juiz, forçando". 
evidente inexistência da ação de direito material em relação a ela. De qualquer modo, a premissa era falha, porque toda sentença é ato de império do juiz, não só a mandamental. E só o juiz pode determinar a execução, dado o monopólio estatal da jurisdição.

Por outro lado, essa conclusão ainda mais se reforça porquanto é lícito à parte para a tutela de seu direito escolher o tipo de tutela jurisdicional que entende mais adequado ao seu interesse, atendidos é claro determinados princípios e as peculiaridades do direito material posto em causa. Por exemplo: mesmo tendo ocorrido a (provável) violação do direito, pode a parte valer-se da tutela declaratória, no lugar da condenatória (conforme expressa permissão do art. $4^{\circ}$, parágrafo único, do $\mathrm{CPC}$ ). Em vez da tutela mandamental, decorrente do (provável) descumprimento da obrigação de fazer ou não fazer, é líciro ao interessado, desprezando a realização in natura do direito, socorrer-se da tutela condenatória ${ }^{100}$.

O mais interessante de tudo é que para a classificação das formas de tutela jurisdicional (as sentenças, por sua força e eficácia, diriam os cultores da ação de direito material) não se mostram decisivos os elementos ligados ao direito material e, por exrensão, à ação de direito material, que dele constituiria parte integrante. O que releva são os elementos vinculados à própria turela jurisdicional, tais como os princípios dispositivo e da demanda, o princípio da adequação (entre o direito material afirmado e o instrumento que serve a sua realização) e os princípios da segurança e da efetividade.

O princípio dispositivo, expressão da liberdade de dispor sobre o próprio direito, permite a opção pela espécie de tutela jurisdicional que a parte entender mais conveniente. Por exemplo; mesmo tendo havido lesão do direito, pode o autor se limitar a pedir a declaração da relação jurídica, ex vi do parágrafo único do art. $4^{\circ}$ do CPC.

O princípio da demanda impõe adstrição ao pedido do autor, vedando ao juiz a prolação de sentença, a favor do autor, de natureza diversa, assim como a condenação do demandado em quantidade superior ou em objeto diverso do que the foi demandado (arts. 128 e 460 do $\mathrm{CPC}$ ), salvo exceções expressamente estabelecidas em lei, a exemplo do disposto no art. 461, caput, do CPC (tutela específica ou resultado prático equivalente). De ral sorte, se o autor optar pela condenação do demandado, não poderá o juiz conceder tutela mandamental.

O princípio da ad equação exige a conformidade do instrumento ao direito marerial, comportando tanto os aspectos subjetivos e objetivo quanto teleológico, os quais devem funcionar de modo simultâneo para que o processo alcance o máximo de eficiência ${ }^{101}$.

\footnotetext{
${ }^{100}$ A respeito do tema, temeto o leitor ao já citado ensaio de minha autoria, O Problema da eficácia da sentença, Repro 112, esp. p. 16.

101 Sobre o tema, o ensaio fundamental de Galeno Lacerda, O Código como Sistema de Adequą̧áo Legal do Processo, in Revista do Instituto dos Advogados do Rio Grande do Sul, comemorativa do cinqüentenário $1926-$ 1976, Porto Alegre, 1976, p. 163-170. Ver, também, C. A. Alvaro de Oliveira, Do Formalismo no Processo Civil, $2^{*}$ ed., \$ão Paulo, Sataiva, 2003, p. 116-120.
} 
O princípio da segurança diz respeito especialmente às garantias de defesa. Por exemplo: não se admite a declaração da existência ou inexistência de mero fato (salvo o incidente de falsidade de documento), mas apenas de relação jurídica, quando em tese já teria ocorrido a incidência da norma; a condenação é a tutela adequada quando se trate de agredir patrimônio alheio, que não pertença ao exeqüente, permitindo-se assim maiores possibilidades de defesa.

O princípio da efetividade impõe a superação de modelos ultrapassados de tutela jurisdicional para certas situações lesivas ao direito material, em prol de mais efícaz e rápida realização do direito material (daí, o surgimento das tutelas executiva e mandamental).

Em todas essas hipóteses, entram em cena elementos típicos da tutela jurisdicional, inexistentes no plano do direito material, preocupado este apenas com regrar a conduta dos sujeitos de direito e suas relações em sociedade. No plano jurisdicional, importa fundamentalmente organizar o processo e melhor instrumentalizar a realização do direito material, para alcançar-se a justiça do caso. Quem não atenta a esse aspecto primacial, obscurece ou mesmo nega a existência de dois planos bem definidos e distintos, o plano do direito material e o do processual.

Não há sentido, v.g, em falar no plano do direito processual em pretensão a reparar. Basta a alegação de que determinado direito sofreu lesão e a formulação do respectivo pedido condenatório. A pretensão de reparação constitui categroria do direito material. Embora possa interessar ao juizo de mériro, não tem vigência no plano estritamente processual, em virtude do monopólio estatal da juris dição Neste plano, o que importa é o agir do autor, por meio da ação processual. Além de the poderem ser dirigidas todas as críticas já realizadas ao conceito de ação material, a faculdade de pretender não passa de flatus vocis se construída sobre o plano material, pois, fora do processo, não se encontra a conduta ativa na qual tal faculdade pode se exercer. Se apresentada, por outro lado, como faculdade de se impor na via judiciária, constitui uma inútil e inadmissivel duplicação da ação processual ${ }^{102}$.

Ademais, os verbos condenar e reparar não são idênticos. Aquele pertence ao plano processual, este, ao material. Outrossim, a condenação promana do Poder estatal, de órgão imparcial, revestido de autoridade e soberania, evisa a reconstruir a situação material que se a firmou ter sido lesada. Nesse sentido reconstrutivo, o verbo condenar é compreensivo do reconhecimento do direito e da lesão, do juízo de reprovação, do comando determinando a reparação e da constituição do título executivo.

Significativamente, quando Pontes de Miranda traça os limites entre as diversas classes de sentença o mais das vezes não emprega elementos de direito material, como seria de

${ }^{102}$ Cf. Elio Fazzalari, Note in Tema di Diritto e Processo, cit, p. 12-14. Como bem observa o jurista italiano, a teoria da pretensão repropõe, com outro nome, aquela mesma inaceitável posição substancial, isto é a faculdade conexa ao direito e näo nascente da lesäo, apresentadia com o nome de actio (nón iam nata). 
esperar por coerência com a teoria da ação de direito material ${ }^{103}$. Assim, na sua perspectiva, a sentença declarativa "É o caso típico de pretensão à sentença (...) sem outra eficácia relevante que a de coisá jul gada material (...) ${ }^{3104}$. A distinção entre a ação executiva real (vg, reivindicatória) e as ações de condenação e executiva por créditos encontra-se na circunstância de que na primeira é pedido que "se apanhe e retire a coisa, que está, contrariamente a direito, na esfera juridica do demandado e se lhe entregue", enquanto nas segundas "os bens estão na esfera jurídica do demandado, acorde com o direito" ${ }^{105}$. Vale dizer, a diferenciação decorre do princípio da segurança: recaindo a execução sobre bens que não são do próprio exeqüente, o processo exige maiores formalidades (daí, o emprego da tutela condenatória), o que não acontece por exemplo com a "ação de despejo", que incide sobre bem do próprio autor (dai, o emprego da tutela executiva). A sentença mandamental se distingue da executiva, porque na primeira há essencialidade do ato estatal e na segunda substituição de atividade do demandado. A diferença estaria em se tratar de ato necessariamente estatal, num caso, e de ato substitutivo da atividade privada, noutro, matéria que nada tem a ver com o direito material. Na verdade, a possibilidade de mandamento - atendidos, é claro, os princípios já assinalados - decorre fundamentalmente do princípio da efetividade, assegurado constitucionalmente.

5. Se, como se procurou demonstrar, não é possível admitir a existência das ditas ações de direito material, sendo por outro lado una e abstrata a ação processual, cumpte ainda examinar em que categoria conceitual podem ser imputados os verbos considerados anteriormente como apanágio de umas e outra.

Nesse aspecto, diga-se em primeiro lugart, que a constitucionalização do direito ao processo e à jurisdição (a exemplo do art. $5^{\circ}$, inciso XXXV, da Constituição brasileira), de envoltas com a garantia da efetividade e de um processo justo (art. $5^{\circ}$, incisos XXXVII, LIII, LIV,LV, LVI), determina também uma garantia "de resul tado", ressaltando o nexo teleológico fundamental entre "o agir em juízo" e a "tutela" do direito afirmado. Essa mudança de perspectiva não permite mais referência à ação como tal - nem à demanda ou à exceção em si, "instrumentos" tecnicamente neutros - mas, sim, aos tipos de pronunciamento e de tutela, que com o exercicio de seus poderes as partes podem obter do processo. Perdeu sentido, portanto, falar ex ante de tipicidade ou de atipicidade da ação, ou recorrer à tradicional

${ }^{103}$ Nada obstante a afirmativa por ele realizada (Tratado das Açóes, tomo I, cit., p. 126) de que "O conceito de açầ, a classificação das ações por sua eficácia, tudo isso consulta o direito material, porçue o fim precipuo do processo é a realização do direito objetivo. Na próprin classificação das açōes e das sentenças, o direito processual tem de atender à eficácia das açōes segundo o direito material. A margem de libetdade que se the deixa é pequena, mas existe".

104 Pontes de Miranda, Tratado das Açôes, totno I, cit., p. 197.

${ }^{\mathrm{t}}{ }^{2}$ Pontes de Miranda, Comentários ao Código de Processo Civil, tomo X, Rio de Janeiro, Forense, 1976, p. 495.496. 
tipologia das ações, visto que a tipicidade e a classificação tipológica constituem atributos ou prerrogativas sistemáticas do "resultado" de mérito (e não do meio processual garantido pela norma constitucional). Põe-se assim em destaque os efeitos jurídicos e os conteúdos variáveis das diversas formas de tatela juris dicional, que dão resposta ao objeto variável da demanda jurisdicional ${ }^{106}$.

Na doutrina alemã, graças aos desenvolvimentos antes ressaltados, a ação ("Klage") tenmina por se converter no poder processual de propor uma "demanda" ao órgão jurisdicional, já que a sua diferenciação tipológica se exaure na diferenciação objetiva dos pronunciamentos de tutela, que o seu exercício permite solicitar e possivelmente obter. Ainda sob este perfil, portanto, a coordenação dos conceitos mais tradicionais ("Rechtsschutzanspruch", "Klagge", "Klagbegehren", "prozessuale Anspruch") em muito conduz a desvalorizar a importância conceitual da "ação", que, em termos práticos, pode ainda se dizer autonomamente identificada como um quid diverso do poder técnico de proposição da demanda de tutela ${ }^{103}$.

Por derradeiro, o próprio tratamento do tema, desenvolvido no presente ensaio e em "O problema da eficácia da sentença", demonstra claramente que condenar, declarar, constituir, mandar ou executar não passam de tipos ou formas de tutela jurisdicional.

506 Ver, nesse sencido, a interessante construção realizada por Lxigi Paolo Comoglio, Note Riepilogative su azione e forme di tutela, rell 'ottica della domanda giudiziale, in Rivista di Diritto Processuale, 48(1993):465-490. Aliás, também é aplicável ao direito brasileiro a aguda observação de Adolfo Di Majo, La tutela civile dei diritti, cit., p. 3, no sentido de que o terreno de unificação e de encontro das aparentes antinomias entre o diretto substancial e o direito processual "è ogg rappresentato dalla Costituzione, la quale si è dichiarata allo stesso modo sensibile non solo all'aspetto della enunciazione di diritti o pretese dei cittadini ma anche a quello della loro tutele, provvedendo a dare a questa tutela garanzia costituzionale (art. 24 Cost.)"

${ }^{107}$ Comoglio, ob. cit., p. 485, nota 90, que cita Thomas-Putzo e Rosenberg-Schwab. Para os primeiros, a "Klage" introduz o juiz e aura à aspiração ao pronuncianento jurisdicional, contendo "o requerimento ao tribunal de outorgar tutela jurídica pela sentença" "das Gesuch an das Gericht, durch Urteil Rechtsschutz zu gewähren"); para os segundos, â açẫo é qualificada tambén como "o tequerimento de outorga de tutela jurídica pela sentença" ("das Gesuch un Gewährung von Rechtschtuz durch Urteil"), configurando assim "a forma de introdução de todo processo" (die Einleitungsform aller Prozesse"). 